\title{
Blødning bak øyet
}
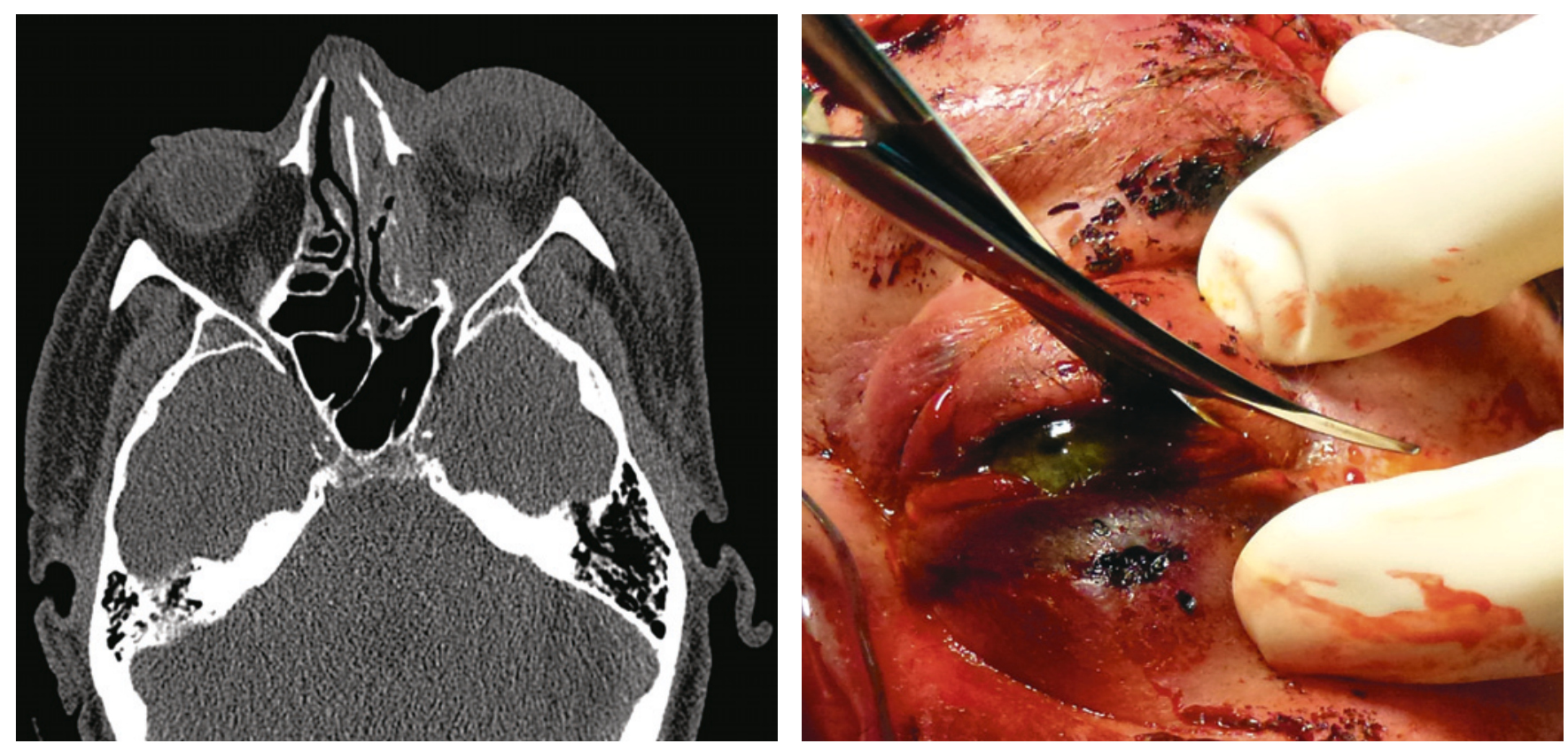

En mann i 60-årene ble innlagt etter en fallskade med traume mot ansiktsregionen. CT av ansikt viste nesefraktur, venstresidig fraktur av orbitagulvet og mediale orbitavegg med dislokasjon samt intraorbitalt hematom. Bulbus var intakt (bildet til venstre). Klinisk undersøkelse viste venstresidig periorbitalt hematom og uttalt proptose. Ved palpasjon var venstre øye spent uten elastisitet. Det forelå svært innskrenket øyebevegelighet av venstre øye i samtlige blikkretninger, nærmest oftalmoplegi. Det var verken direkte eller indirekte lysreaksjon og fullstendig tap av synet på venstre øye. Intraokulært trykk på venstre øye var målt til $70 \mathrm{~mm} \mathrm{Hg}$.

Bruddskader i orbita kan medføre blødninger som gir intraorbital trykkstigning med risiko for permanent synstap. Tilstanden er sjelden og benevnes som traumatisk retrobulbær blødning. Den affiserer $0,3-0,6 \%$ av pasienter med zygomatikoorbitale frakturer (1). Traumatisk retrobulbær blødning kan føre til kompartmentsyndrom og krever rask intervensjon for å hindre irreversibel skade som kan oppstå etter 90-120 minutters mangel på tilstrekkelig blodforsyning i orbita. Tilstanden kan utvikles rett etter skaden eller flere timer senere.

Ved traumatisk retrobulbær blødning skaper blødning og ødem økt intraorbitalt trykk i septum orbitale. Når trykket øker, presses orbitainnholdet mot nervus opticus, og iskemiske skader oppstår grunnet kompresjon av intraorbitale kar. Det er uavklart om det er det direkte trykket mot nervus opticus, kompresjon av karforsyningen til nerven eller redusert blodforsyning $\mathrm{i}$ arteria centralis retina som gir synstap. Pasienter som er antikoagulert er særlig utsatt for synstap. Det kliniske bildet domineres av smerte, proptose, redusert visus, subkonjunktivalblødning, periorbital hevelse, oftalmoplegi og eventuelt manglende afferent pupillrefleks. Visusreduksjon som utvikler seg gradvis kan være tegn på en reversibel kompresjonsskade og ikke direkte mekanisk skade. Intraokulært trykk kan også være svært forhøyet.

Vår pasient oppfylte alle kriterier for traumatisk retrobulbær blødning. Fire timer etter innkomst ble det utført dekompresjon ved lateral kantotomi og kantolyse i lokalanestesi (åpning av laterale øyevinkel og spalting av det laterale kantale ligament) (bildet til høyre). Etter operasjonen gikk proptosen raskt tilbake og etter 15 minutter var det intraokulært trykk på $20 \mathrm{~mm} \mathrm{Hg}$. Pasienten fikk dessverre ikke bedre syn i dette tilfellet. Traumatisk optikusnevropati vurderes derfor som en mulig tilleggsdiagnose.

Det er viktig at leger i traumemottak og vakthavende spesialister i øyesykdommer og øre-nese-hals-sykdommer kan diagnostisere og behandle denne tilstanden ved å utføre lateral kantotomi og inferior kantolyse. Dette kan hindre permanent synstap.
Pasienten har gitt samtykke til at artikkelen blir publisert.

\section{Helge Risheim}

helge@kirurgiklinikken.no

Avdeling for kjevekirurgi

Oslo universitetssykehus, Ullevål

og

Kirurgiklinikken

Monica Sneve

Øyeavdelingen

Oslo universitetssykehus, Ullevål

Helge Risheim (f. 1966) er tannlege og spesialist i plastikkirurgi og i maxillofacial kirurgi. Forfatter har fylt ut ICMJE-skjemaet og oppgir ingen interessekonflikter.

Monica Sneve (f. 1974) er lege i spesialisering. Forfatter har fylt ut ICMJE-skjemaet og oppgir ingen interessekonflikter.

\section{Litteratur \\ 1. Chen YA, Singhal D, Chen YR et al. Management of acute traumatic retrobulbar haematomas: a 10 -year retrospective review. J Plast Reconstr Aesthet Surg 2012; 65: 1325-30.}

Mottatt 31.5. 2013, første revisjon innsendt 24.2. 2014, godkjent 8.9. 2014. Redaktør: Tor Rosness.

Engelsk oversettelse på www.tidsskriftet.no 